\title{
Stratified Cuboidal Epithelium
}

National Cancer Institute

\section{Source}

National Cancer Institute. Stratified Cuboidal Epithelium. NCI Thesaurus. Code C33621.

Epithelium consisting of multiple layers of cells in which the top layer of cells are boxshaped. It is commonly found in large gland ducts such as sweat gland ducts. 